\title{
FOREIGN HOUSING MARKETS: QUESTIONS OF PRICE POLICY
}

\author{
Mariia Ermilova ${ }^{1, \square}$, Evgeny Kalinkin $^{1}$, Elena Semenkova ${ }^{1}$, Kira Kalinkina ${ }^{1}$ \\ ${ }^{1}$ Plekhanov Russian University of Economics, Department of financial management, 117997, Moscow, \\ Russia
}

\begin{abstract}
The housing market is one of the most important segments of the economy of any country. As part of the study, it is shown that it is not enough to consider the housing market financing system only in the organizational and structural aspect. The application of a structurally functional approach is essential, which will improve the efficiency of market financing. The author determines the need for the formation of autoregulators that can reduce the need for manual control of the economy of the housing complex and the state, which is especially important in the modern economic system. The study identified such auto-regulators as the inclusion of borrowers in the quality management system and the usefulness of housing finance; organization of interaction of market and state financing based on the principles of public-private partnership; the need for a system of indicators to assess the development of the Russian housing market, improving the information support of financial markets; the formation of an open system for monitoring the status of the housing market financing system.
\end{abstract}

\section{Introduction}

Currently, one of the most significant issues is the provision of housing for citizens, which is necessary for the entire population. In addition, the housing market is interesting in terms of investing temporarily free cash. The development of the housing market is also necessary for the state, one of the tasks of which is the implementation of the socio-economic task of having housing for citizens. At the same time, business entities are considering the housing market as a segment of the market for effective investments. Investing in the housing market not only in Russia but also in other countries has long been a profitable business. Such investments are much more accessible and understandable for society than the same stock market, the activity on which is obscure to the average citizen.

In the framework of this study, the goal is to identify the most investment-attractive housing markets in terms of pricing policy. In order to achieve this goal it is necessary to solve such problems as:

\footnotetext{
${ }^{\square}$ Corresponding author: masha080487@mail.ru
} 
- identify at what stage of the cycle are the housing markets of different countries;

- highlight countries with overstated and lowered housing prices;

- analyze the pricing policy for premium real estate;

- identify countries in which housing is most affordable for purchase.

Analyzing the studies of Russian and foreign authors, we can conclude that the main attention is paid to assessing the prices that are offered to buyers, as such, there is no formation of countries according to accessibility groups and pricing policies in the housing market. Not so many works are devoted specifically to the investment component of housing in various countries. The authors do not conclude that with the help of an asset such as real estate, certain financial flows can be formed. Some researchers largely elucidate the issues of what factors affect the formation of housing prices, build econometric models for assessing each factor.

Although it is the investment component in such an asset as real estate that plays an important role for the sustainable development of cities.

Basten and Koch (C. Basten, C. Koch, 2015) [1] in their study assess the impact of housing prices on supply and demand in the mortgage market.

Canepa A., Khaled F. (2018) [2] and Berg N., Jha N., Murdoch J.C. (2012) [3] analyze the relationship of the housing market and its prices with credit risks and other risks inherent in the market.

Bandyopadhyay A., Saha A. (2011) [4] already in a specific market in India consider the characteristics of the housing market that cause the greatest risks, including taking into account the price aspect.

Zhu B., Betzinger M., Sebastian S. (2017) [5] associate stability in the housing market with a specific monetary policy and structure of the mortgage market. This is a more extended list of indicators than previously mentioned authors. At the same time, the price factor remains significant in the analysis.

Some researchers pay special attention to price factors influencing the development of the housing market and its financing, putting prices in priority (Wei, Q., Gu, X., 2013 [6]).

Domestic researchers note the significance of the price factor in assessing the development of the market and its attractiveness in the eyes of investors (Korolkova D., Gerasimova N., Tkachenko G.I., 2014) [7].

Grinenko S. (2004) [8] and Poorvu, W.J. (2003) [9] provide a wider list of indicators for assessing the development of the housing market, including in terms of the investment component. However, they do not focus on the price factor, but analyze it in aggregate.

Foreign authors (Reed R., Wu H., 2010 [10]) see the importance of analyzing the cyclical nature of the housing market, which generally affects market development and pricing.

E. Kharebov, I. Gigolaeva, M. Karazhaev (2016) [11], G. Galieva (2016) [12], M. Akhmadeeva, D. Andreeva (2017) [13] in their studies indicate that accessibility housing is estimated including, and prices in the market. Since credit policy and, in general, the solution of socio-economic issues also depend on this factor.

Some consider real estate investments as separate investment or venture projects (Zhdanova, O.A., Milyaev, K.V., 2016 [14]), so the assessment of the price parameter is a priority.

Murzin A. (2013) [15] makes a large study on the housing market in terms of its assessment indicators, development trends, where the cost aspect plays an important role.

However, not all of these studies include a broader analysis of the housing market in terms of assessing pricing policies, the main trends that may be useful to potential investors. In the presented study, attempts will be made to a more detailed analysis of foreign housing markets in terms of price factor 


\section{Methods}

The economic recovery after the global financial crisis in 2014 allowed us to observe some positive trends in world housing markets. Loan conditions for loans became more accessible to consumers, interest rates in European countries, the UK and the United States remained and remained at a low level, the employment level of the population increased, and consumer confidence strengthened. The recovery in global markets after the financial crisis predetermined the growth of purchasing power and once again determined the desire of investors to acquire various real estate.

Table 1. Cycles of housing markets

\begin{tabular}{|c|c|c|c|}
\hline Peak stage & Fall stage & Growth stage & Bottom stage \\
\hline Belgium & Greece & Germany & Netherlands \\
\hline Norway & Spain & United Kingdom & France \\
\hline Canada & & USA & Italy \\
\hline
\end{tabular}

Analysts conducted an analysis of a number of countries according to a predetermined criterion, which will be given below in the table and based on this they were able to group countries according to the selected attribute (table 2). Next, we indicate how the states were divided, depending on the selected criterion:

- state, with inflated prices for residential real estate;

- state with low prices for residential real estate;

- state with a balanced cost.

The peculiarity was that over time, the number of countries with balanced supply and demand gradually began to increase, which is a positive trend in housing markets.

Table 2. The gradation of housing markets in the ratio between income and solvent demand

\begin{tabular}{|c|c|c|}
\hline $\begin{array}{c}\text { Excessively high residential } \\
\text { property prices }\end{array}$ & $\begin{array}{c}\text { Excessively low residential } \\
\text { property prices }\end{array}$ & Price balance \\
\hline Australia & Germany & Austria \\
\hline Belgium & Greece & Iceland \\
\hline United Kingdom & Ireland & Italy \\
\hline Denmark & Portugal & Suxembourg \\
\hline Spain & Slovenia & USA \\
\hline Canada & Japan & Switzerland \\
\hline Netherlands & & \\
\hline New Zeland & & \\
\hline Norway & & \\
\hline North Korea & & \\
\hline Finland & & \\
\hline France & & \\
\hline Sweden & & \\
\hline
\end{tabular}

The data presented in the table show that there are more markets with inflated value of residential real estate. Largely, these are developed European countries, which is understandable because of their effective economic development, which enables the housing market to strengthen. Either Low prices in those markets where effective mechanisms for financing the purchase of housing operate, or the country itself has any problems in economic terms. 


\section{Results and Discussion}

Because of the analysis and classification of countries according to the price criterion, we consider the results in more detail.

The Belgian, Canadian and Norwegian markets are showing an increase in housing prices, and this trend continues. Criteria that may affect a further change in the situation in these markets may be an increase in interest rates on mortgages or a change in the state's revenue that is allocated for the development of housing markets, or a change in the situation of construction companies that will determine a further increase in prices. Countries are quite stable now and the consequences of the crisis did not particularly affect them, so we can say that in the future it may be an investment-attractive housing market. If, even at the time of the onset of the crisis, the price in Norway first decreased, and then steadily went up, despite the rapid development of the crisis, this undoubtedly also indicates the prospect of investing in this housing market. One of the criteria that may somehow affect the change in the cost of housing in Norway may be a tightening of lending conditions, but so far, there are no prerequisites for this. At the same time, the annual increase in prices in the housing market may be $2-3 \%$. Prices for Greek, Spanish, Portuguese real estate continued to decline until the onset of the crisis and continued until the 15 th year of the 21 st century. Further, after the market settled down, it was possible to observe a gradual recovery of pre-crisis indicators and rising prices for residential real estate. This indicates the strengthening of the economic situation. This situation in the housing markets of these countries may attract potential investors who will be ready to invest their temporarily free cash in the economies of these countries. Especially after the crisis and the gradual recovery of markets, their prices will be much more attractive than in other European countries. The German market also suffered losses during the global financial crisis, and even up to 2014 it was impossible to talk about its full recovery. However, the efforts made by the state to restore the economy as a whole and the measures taken by the state made it possible in the following years to ensure stable growth in housing prices within $6 \%$ or more.

The change in property prices in Japan is ambiguous, since here the cut is carried out separately by land and by the price of the residential property itself. Prices for these two assets are mixed. In addition, problems at the state level in economic policy also leave their mark. The depreciation of the yen against the US dollar is also reflected in a certain way on the 6th housing market. For foreign investors, residential real estate, and commercial real estate in Japan is of quite serious interest. Such real estate provides significant income for the year of its use. According to analysts, such a return can reach 5\% per year. The most frequent buyers of Japanese real estate are residents of Singapore, Hong Kong and Taiwan.

In addition to the fact that in some states real estate prices are overstated or underestimated taking into account the average incomes of the population, there are countries in which there is an almost direct balanced ratio between the incomes of citizens and the cost of housing. These countries were previously listed in table 2. In Switzerland, overall, the situation in the housing market and in the economy is quite balanced. However, it is worth noting that even in the Swiss market, it is impossible to give a single assessment to all regions of the country and the pricing policy may be different depending on the specific territory. As in most countries, in Switzerland the calculation is based on the average values of the indicators taken into account. Data on average household incomes and average prices for residential real estate presented for the formation of a model for the country do not take into account the geographical location of the regions.

One of the most attractive investment areas is investments in real estate located in resorts. Such regions exist in countries that have been analyzed. A feature of this segment is that when calculating the price of housing at resorts, the mortgage rate is not taken into account. 
Largely, resorts are a personal desire of a consumer who has temporarily free cash and chooses this type of real estate for their investment.

Demand comes from wealthy buyers, since prices are quite high. Table 3 shows how housing prices at resorts changed during and after the global financial crisis. Largely this European countries, which are included in the previous samples presented earlier.

Table 3. Dynamics of housing prices in resort areas.

\begin{tabular}{|c|c|c|}
\hline Terrain & $\begin{array}{c}\text { Price change } \\
\text { since 2008, \% }\end{array}$ & $\begin{array}{c}\text { Rating } \\
\text { since 2014 }\end{array}$ \\
\hline Evian, France & $-25 \%$ & Without changes \\
\hline Chamonix, France & $-20 \%$ & Growth \\
\hline Montreux, Switzerland & $-15 \%$ & Without changes \\
\hline Gold Coast, Zurich, Switzerland & $-4 \%$ & Without changes \\
\hline Cape Antibes, France & $-20 \%$ & Decline \\
\hline Florence, Italy & $-20 \%$ & Growth \\
\hline Praia da Luz, Portugal & $-30 \%$ & Without changes \\
\hline Palma de Mallorca, Spain & $-30 \%$ & Decline \\
\hline
\end{tabular}

Largely, wealthy buyers choose housing at resorts. Some get for personal relaxation, others are rented out to increase their income and cover the costs necessary for servicing real estate. In general, if the area is in demand among tourists, then this housing can be a good object for renting and obtaining sufficient income. In this regard, we can talk about the profitability of such investments.

The next category of residential real estate, the investment in which will be analyzed, is business-class housing. It is also a resort property that is a rather expensive asset, but it can also bring substantial income to its owner if it was not acquired for personal use. Next, we will consider the dynamics of changes in prices for such types of real estate in different countries. It will be the countries of the Western European, Middle Eastern and Asian-Pacific regions. In addition, we will analyze how prices change in the domestic business class housing market. The main criteria relating to housing in the business class is the price category, and accordingly, buyers are usually people with a high and very high-income level.

The main countries to be evaluated are Russia, Australia, Great Britain, Germany, Hong Kong, China, Morocco, USA, France, and Japan.

Next, consider the change in property prices in the following countries.

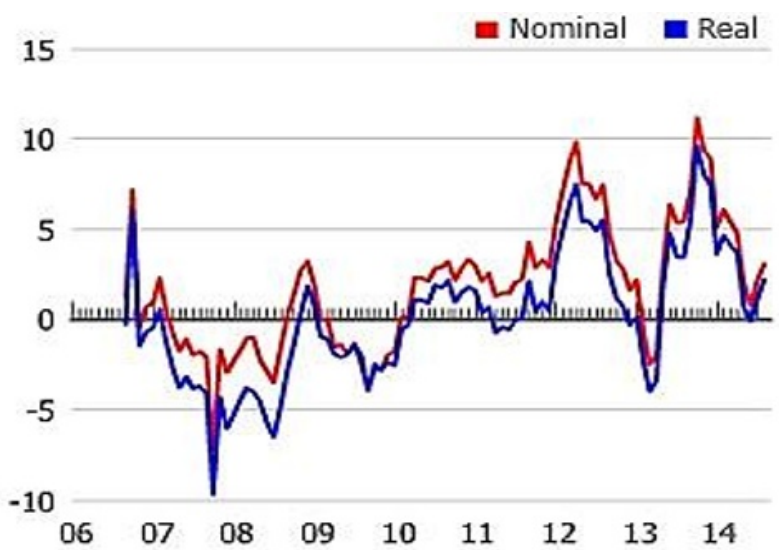

Fig. 1. The cost per square meter of business-class housing in Germany. 
As can be seen from the figure, business class housing prices are constantly fluctuating and it is impossible to note a constant single tendency to increase or decrease. The market is volatile. Of course, the German economy is one of the most developed, the socio-economic development is stable, and the income level of the population is constantly growing with the corresponding economic cycle. All of the above affects the amount of business-class housing sold and the prices that are set for it. Accordingly, according to the graph, it can be seen that if the price goes down, then there are disasters and crises in the country's economy that force the market to react to the market by lowering prices.

It is essential for the European continent that even if countries have common borders, approximately the same economic development, participation in international economic organizations, this does not mean that prices will be similar in level, and housing quality will be the same (Germany, France, Fig. 1,2). There is no dependence of these countries on economic development and pricing policy in the housing market.

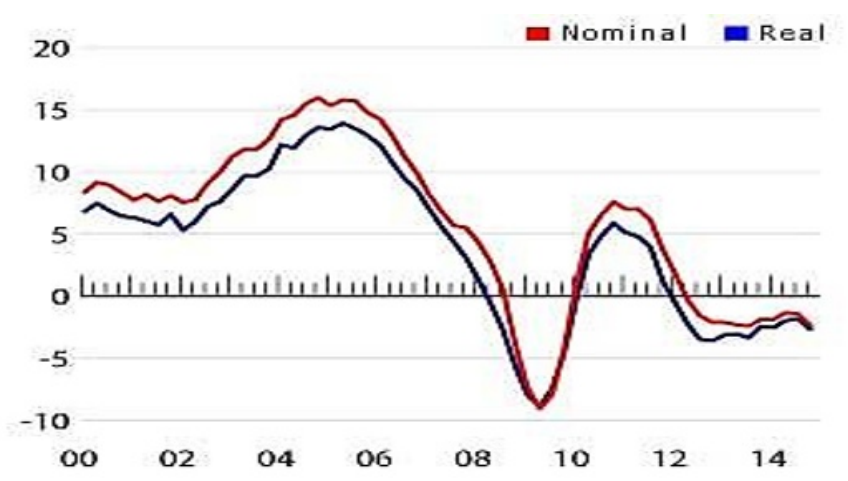

Fig. 2. The cost per square meter of business-class housing in France.

After analyzing the data of both figures, we can see a significant difference in prices between them and the very dynamics of prices. At the same time, Germany shows greater stability in these parameters than France.

Next, we consider the situation in Russian cities regarding the pricing policy for the business class-housing segment. Largely in Russia, an important factor that affects housing prices is the cost of a barrel of oil. Since our country is a raw material, we can't get away from taking this factor into account. Here, you immediately need to talk about credit policies in relation to business entities and how they are affected by the price of oil.

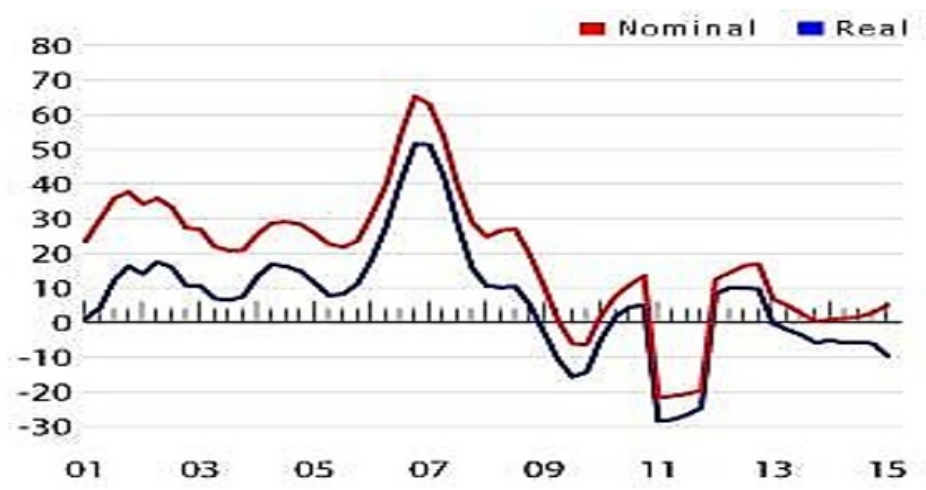

Fig. 3. The cost per square meter of business-class housing in Russia. 
The data obtained indicate a correlation between the dynamics of oil prices and a square meter of business-class housing. Calculations show that this coefficient can reach -0.9 . Moreover, in various periods its change is not so significant. Thus, the statistical dependence of the dynamics of changes in the cost per square meter of housing and a barrel of oil is significant.

During the war, US policy significantly affected the housing markets of other countries, and indeed the economies of the countries as a whole. This led to the interconnection of price changes in individual countries with each other. These countries include Britain, Germany and the United States. The influence of the US economy during the war period predetermined that the cycles of development of housing markets in these countries quite often coincide. If one grows, then this will predetermine the growth of another, and vice versa.

In addition to these, another dependent housing market on US development is Japan's housing market. He is enough volatiles, is influenced by a large number of factors, not only related to the United States, but in principle within the framework of the world system.

At the same time, comparing the dynamics of prices in European markets and in Japan, a coincidence in development is unlikely to be found. This is reflected not only in ordinary housing, but also in business class.

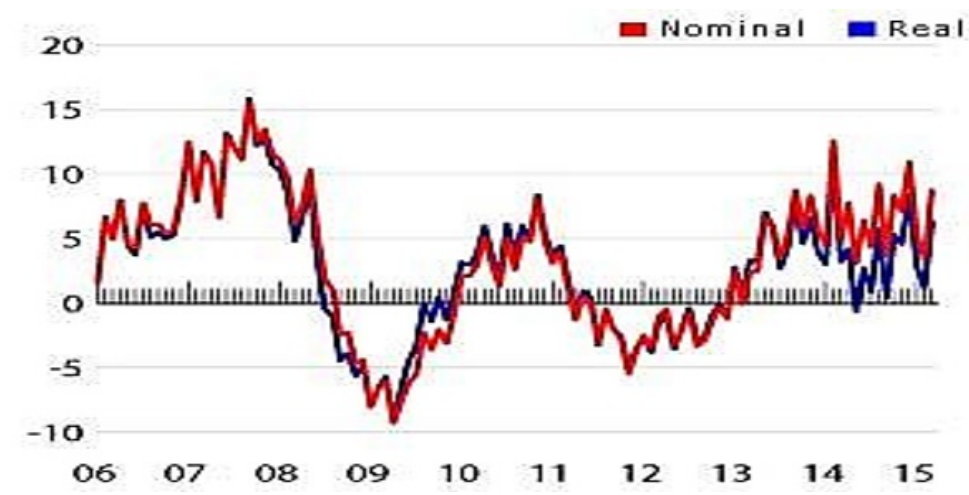

Fig. 4. The cost per square meter of business-class housing in Japan.

Hong Kong's housing market volatility is even more significant than the previously mentioned countries. First, such changes are associated with the role of Hong Kong in the global economy, in the global financial system. This country has a significant impact on other countries in the market countries. In certain periods, the Hong Kong market is experiencing a decline, such as during the global financial crisis. However, at the end of it, by the beginning of 2016, the housing market had grown significantly over $20 \%$.

Next, we look at another close to the previously analyzed markets - the Chinese housing market. Most of the time there was stagnation in the market, and the state that has recovered a bit after the crisis has tried to provide cheaper loans and develop the economy. However, the epidemic again worsened the situation in general in the market and in housing in particular. While experts do not undertake so clearly to predict how long the Chinese market will be able to get out of the crisis. The situation for business-class housing has worsened significantly. Potential foreign investors excluded this market for themselves as such, as a place for investment.

The next market to analyze is the Moroccan housing market. From the point of view of economic development, this country is quite interesting for the investor. The government seeks to minimize political conflicts and participation in them, so the economy is quite stable. 
For a foreign investor, real estate in Morocco may be interesting for rental purposes and short-term personal residence.

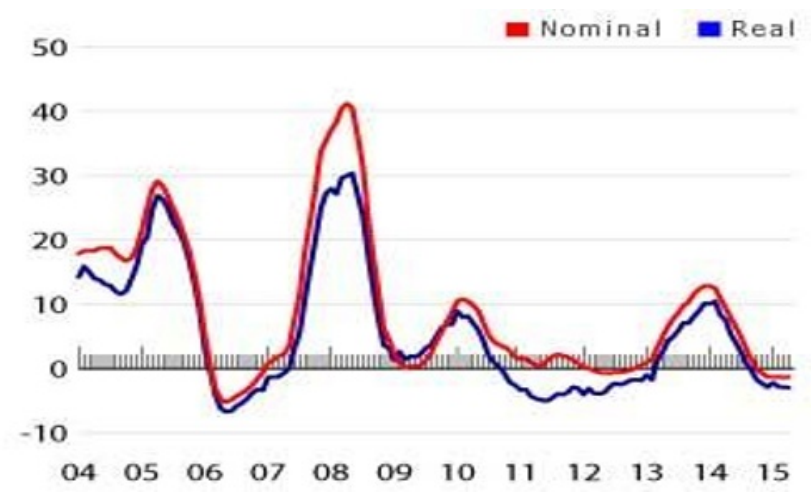

Fig. 5. Cost per square meter of business-class housing in China.

Every year it becomes an increasingly popular destination for citizens of many countries. Therefore, investors see the promise of such investments. A good location makes this country even more attractive for tourists. The government itself is developing international relations, actively trading in goods of its own production, which are in demand by other countries. A number of analysts talk about the promising growth of this market and even greater attractiveness for investors.

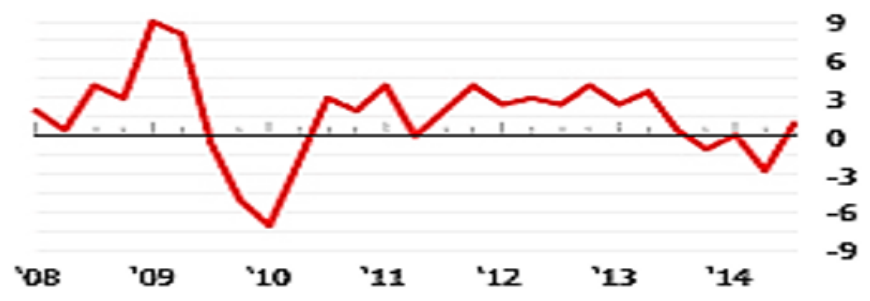

Fig. 6. Cost per square meter of business class housing Morocco.

In conclusion, a few words will be given to the Australian market. Despite the global financial crisis, that has affected this country. The housing market quickly recovered and became again interesting for investors in terms of investing temporarily free cash, so there are prospects for further market growth.

Close interaction with other countries increases interest in the housing market in Australia, in its facilities not only economy, but also business class. A fairly pleasant climate is attracting an increasing number of investors.

Thus, the analyzed data show price changes in various housing markets, which are the most sought after by investors.

\section{Conclusion}

The figure below shows the dynamics of the cost per square meter of residential real estate in a number of countries as a percentage. 


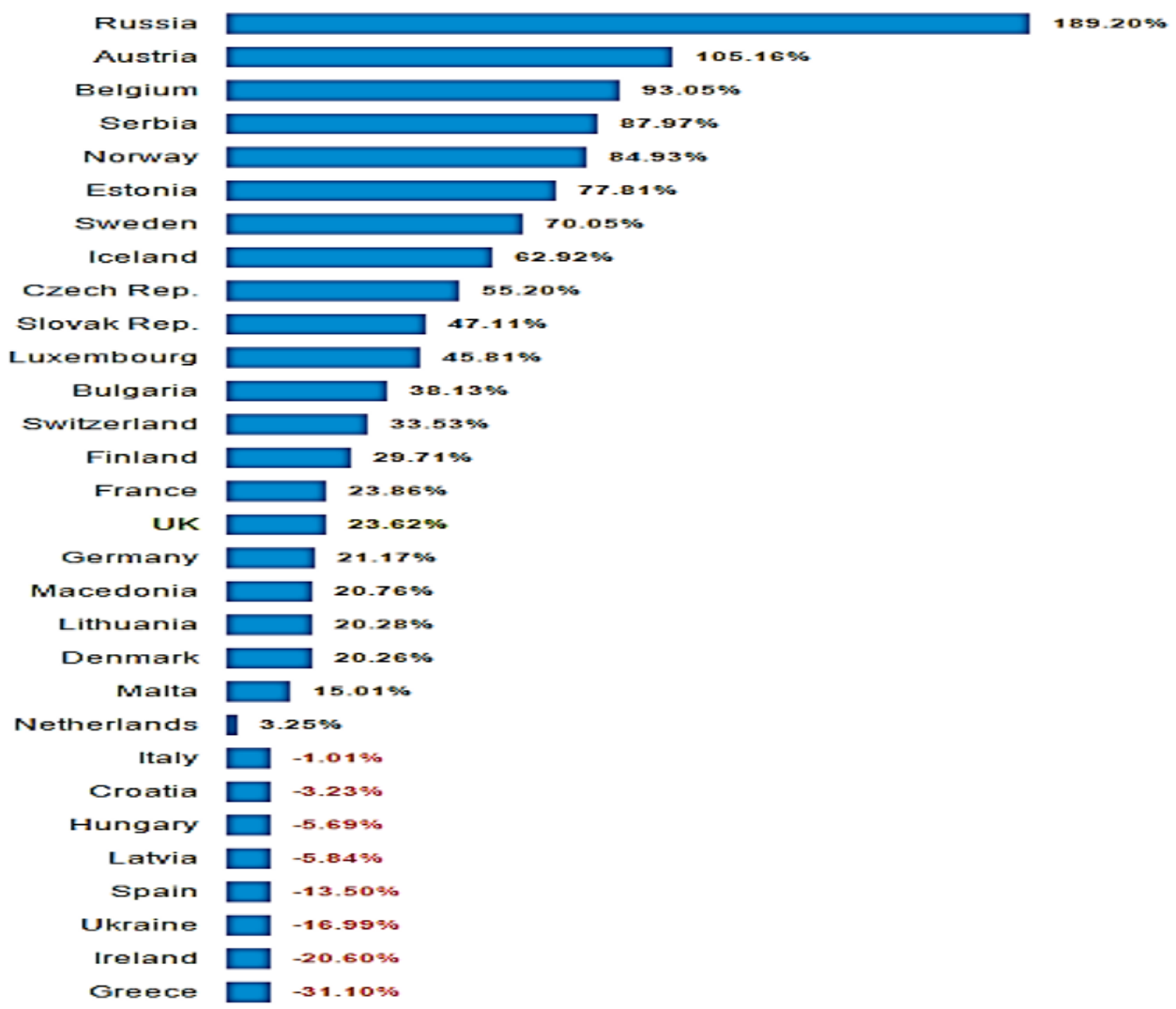

Fig. 7. Analysis of the growth in the cost of housing in the analyzed countries.

The data in the figure shows a significant superiority in the growth of housing prices in Russia. More leaders include Belgium, Austria, Estonia. The markets of Italy, Spain, Latvia, Greece, Ukraine, and Ireland are less successful in this.

The results of the analysis say our country is moving significantly along the path of rising prices, but so far, it is fourth in the world. In view of the policy of providing citizens with affordable housing, leadership in such a market is not the best strategy. Since for such leadership both the country's economic development and the income level of the population should be an order of magnitude higher. So far, our country is among the attractive for investment in the housing market along with developed countries. If you choose based on the lowest price, then it will be the markets of Bulgaria, Moldova, Montenegro. Thus countries remain in demand among middle-income Russian citizens.

When choosing an investment object, investors need to carefully analyze the market at not only the present time, but also the forecast indicators provided by analysts. This will allow you to invest as efficiently as possible.

\section{Reference}

1. C. Basten, C. Koch, Journ. of Hous. Econ. 30, 1-22 (2015)

2. A. Canepa, F. Khaled, Inter. Jour. of Finan. Stud., 6 (50), 1-23 (2018)

3. N. Berg, N. JHA, J.C. Murdoch, Elsevier, 193-203 (2012)

4. A. Bandyopadhyay, A. Saha, Jour. of Econ. Stud., 38 (6), 703-724 (2011) 
5. B. Zhu, M. Betzinger, S. Sebastian S., Journ. of Hous.Econ. 37, 1-21 (2017)

6. Q. Wei., X. Gu, Inter. Jour.of Appl.Math. and Stat. 49 (19), 26-33 (2013)

7. D. Korolkova, N. Gerasimova, G. Tkachenko, Fund. Research. 9(3), 635-638 (2014)

8. S. Grinenko, TRTU, 107 (2004)

9. W.J. Poorvu, Harvard Business School. 7, 25 (2003)

10. R. Reed R., H. Wu, Prop. managem. 28(1), 33-46 (2010)

11. E. Kharebov, I. Gigolaeva, M. Karazhaev, Econ. and Entrepren. 10-2(75), 831-834 (2016)

12. G. Galieva, Competitiveness in the glob. world: econ., scien., techn. 7-1(19), 87-90 (2016)

13. M. Akhmadeeva, D. Andreeva, Innovative development of the economy. 2(38), 17-31 (2017)

14. O.A. Zhdanova, K.V Milyaev, Intern. Journ.of Appl. Bus. and Econ. Resear. 14(14), 785-798 (2016)

15. A. Murzin, M.: Phoenix, 382 (2013). 